\title{
Brown trout thermal niche and climate change: expected changes in the distribution of cold-water fish in central Spain
}

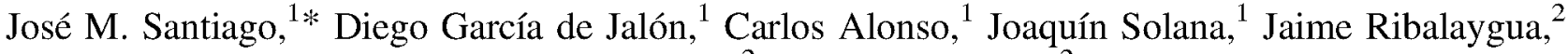 \\ Javier Pórtoles $^{2}$ and Robert Monjo ${ }^{2}$
}

\begin{abstract}
This paper addresses the determination of the realized thermal niche and the effects of climate change on the range distribution of two brown trout populations inhabiting two streams in the Duero River basin (Iberian Peninsula) at the edge of the natural distribution area of this species. For reaching these goals, new methodological developments were applied to improve reliability of forecasts. Water temperature data were collected using 11 thermographs located along the altitudinal gradient, and they were used to model the relationship between stream temperature and air temperature along the river continuum. Trout abundance was studied using electrofishing at 37 sites to determine the current distribution. The Representative Concentration Pathways RCP4.5 and RCP 8.5 change scenarios adopted by the International Panel of Climate Change for its Fifth Assessment Report were used for simulations and local downscaling in this study. We found more reliable results using the daily mean stream temperature than maximum daily temperature and their respective 7 days moving average to determine the distribution thresholds. Thereby, the observed limits of the summer distribution of brown trout were linked to thresholds between 18.1 and $18.7^{\circ} \mathrm{C}$. These temperatures characterize a realized thermal niche narrower than the physiological thermal range. In the most unfavourable climate change scenario, the thermal habitat loss of brown trout increased to $38 \%$ (Cega stream) and $11 \%$ (Pirón stream) in the upstream direction at the end of the century; however, at the Cega stream, the range reduction could reach $56 \%$ due to the effect of a 'warm-window' opening in the piedmont reach.
\end{abstract}

\section{INTRODUCTION}

Temperature has a large influence on the biological success of fish and other aquatic organisms (Nukazawa et al. 2011), acting as a fundamental driver affecting the energy budget, growth (Elliott et al. 1995; Elliott and Hurley 1999, 2001; Forseth et al. 2009; Elliott and Allonby 2013) and other physiological functions of fish (Jeffries et al. 2012; Warren et al. 2012; Lahnsteiner and Leitner 2013; Vornanen et al. 2014), such as ecological relationships (Hein et al. 2013; Fey and Herren 2014) and even 'personality' (Frost et al. 2013). Temperature is a component of the ecological niche, and it is named 'thermal niche' (consolidated term in bibliography: e.g. Magnuson and Destasio 1996; Wehrly et al. 2003; Angilletta 2009; Finstad et al. 2011).

Spotila et al. (1989) defined physiological niche as the set of environmental conditions under which a species can

persist (cf. Hutchinson 1957; Leibold 1995). 'Persist' means that $\mathrm{dN} / \mathrm{dt}>0$ (May and McLean 2007). The temperature range at which the brown trout has a positive somatic growth was established by several works (3.6-19.5 $5^{\circ} \mathrm{C}$ in Elliott et al. 1995 ; approximately $5-23^{\circ} \mathrm{C}$ in Forseth et al. 2009). This range of thermal efficiency is closely linked to the fundamental physiological niche for thermal conditions (fundamental thermal niche) (Angilletta 2009) for brown trout. This range must be at most equal to the tolerance range of temperatures as defined by the temperatures of incipient lethality $\left[0-25^{\circ} \mathrm{C}\right.$, approximately (Elliott and Elliott 2010)]. The general approach for thermal niche as defined by Magnuson and Destasio (1996) (the preferred temperature $\pm 5^{\circ} \mathrm{C}$, accepting that fish spend all their time within this interval) seems to approach to the realized niche better than to the wider fundamental thermal niche. Nonetheless, the optimal growth temperature is influenced by fish uptake and fish size. Forseth and Jonsson (1994) reported that the optimal growth temperature for fish eating brown trout was $16^{\circ} \mathrm{C}$, which is higher than that found for trout fed with pellets (average: $13 \cdot 5^{\circ} \mathrm{C}$, Forseth et al. 2009) or invertebrates (average: $13 \cdot 1^{\circ} \mathrm{C}$ 
Elliott et al. 1995). On the other hand, the optimal temperature changes with fish size (Handeland et al. 2008, Morita et al. 2010). Thus, it is not straightforward to give one figure for optimal temperature for growth in a species.

Stream temperature is strongly correlated with air temperature (Edinger et al. 1968; Mohseni et al. 1998; Bogan et al. 2003; Caissie 2006), and an increase in temperature due to global warming can dramatically disturb aquatic ecosystems (Wade, 2006; Woodward et al. 2010). Climate change has the potential to increase or decrease habitat availability (Hughes 2000, Parmesan 2006). By this reason, the distribution of cold-water species such as brown trout and other salmonids is likely to suffer a displacement in the lower limits of their range to higher altitudes and latitudes (i.e. Crozier et al. 2008, Beer and Anderson 2013, Ruesch et al. 2012, Eby et al. 2014). The simulation of climate scenarios can help us assess the magnitude of the loss of suitable habitat ranges, not only in terms of the distribution range but also in terms of the physiological efficiency (i.e. Hari et al. 2006; Jonsson and Jonsson 2009; Wenger et al. 2011; Ayllón et al. 2013). According to Haldane's second hypothesis (Haldane 1956), these losses are more likely to be noticed at the limits of the thermal axis of the species' ecological niche. This is the case for several Iberian populations of brown trout, which inhabit the southern edge of the native distribution of this species.

The variation of the thermal regime, similar to other physical variables, is a continuum within a given stream network that tracks the geographical and physiographical changes along the network (Vannote et al. 1980). To represent this continuum, modelling can be a useful tool. Many deterministic, regressive and stochastic models have been developed to relate both air temperature and stream temperature. Deterministic models use an energetic budget to forecast stream temperature (Theurer et al. 1984; Evans et al. 1998), whereas regressive and stochastic models mainly use the relationship with air temperature to predict stream temperature (Caissie et al. 1998, St-Hilaire et al. 2011). Although deterministic models have a high explanatory strength, regressive and stochastic models may also exhibit high predictive power. Moreover, the type of data needed by the deterministic models is much harder to collect than the data needed by the regressive and stochastic models. Meteorological services have a large amount of spatial and temporal information on air temperature, which makes this variable very attractive for forecasting future stream thermal behaviour from climatic models.

The aim of this study is to quantitatively describe the influence of temperature on trout distribution along streams and determine how it is affected by climate change. For this purpose, we empirically determined the threshold temperature that characterizes the distribution limits of trout in the study area. We selected the best predictor among different expressions of temperature, namely the daily mean temperature for 7 consecutive days (studied as a series, not averaged), the weekly moving average of daily mean temperatures, the daily maximum temperature for 7 consecutive days and the weekly moving average of daily maximum temperatures. Next, we adopted the best indicator to create projections based on the latest climate change scenarios (Taylor et al. 2009, adopted by IPCC 2013). In this study, global climate models (which have coarse resolution) were transformed to a local scale using a statistical downscaling method to obtain the local outcomes. We continuously modelled the stream temperature throughout the length of the streams at a daily resolution and then simulated the change of the thermal habitat. Our methodology aims to decrease the necessary steps to reach this goal by reducing the statistical uncertainty.

\section{MATERIALS AND METHODS}

\section{Study site}

Fieldwork was conducted in two tributaries of the Duero River [Cega and Pirón streams $\left(40^{\circ} 59^{\prime} \mathrm{N} ; 3^{\circ} 50^{\prime} \mathrm{W}\right)$, central Spain]. The Cega and Pirón streams are 135 and $92 \mathrm{~km}$ long, respectively. The Pirón stream is the main tributary of the Cega stream. There is only one major dam in Pirón (Torrecaballeros dam; capacity: $0.324 \mathrm{hm}^{3}$; maximum depth: $26 \mathrm{~m}$; altitude: $1390 \mathrm{~m}$ a.s.1.), and there are no dams in Cega that are able to significantly alter the flow regime. Granitic meta-detritic geology dominates the headwater basins. A karst belt occurs in the piedmont zone, giving way to large sand flatlands of detritic-tertiary origin with detritic-quaternary alluvial deposits.

Gauging stations 2016 and 2714 (official network codes; at 938 and $838 \mathrm{~m}$ a.s.l., respectively) in the Cega stream and 2057 ( 869 ma.s.1.) in the Pirón stream were used to characterize the hydrological regime of both streams. Snowmelt and winter-spring rainfall are important in these basins. Thus, an 'extreme winter' becomes an extended 'moderate winter' (Haines et al. 1988). Dry summers and permeability in flatlands cause the appearance of dry reaches in channels of the Cega and Pirón streams. The annual runoff averages of the last 20 years (to 2011) were 88.6 and $34.3 \mathrm{hm}^{3}$ at stations 2016 and 2057 , respectively. Gauging station 2714 began to operate in 2004, and the annual runoff average in 2011 was $52 \mathrm{hm}^{3}$ (MAGRAMA 2014).

\section{Data collection and testing}

Observed maximum and minimum air temperatures were obtained from AEMET (Spanish Meteorological Agency) station number 2516 in Ataquines. This meteorological station was selected because it is the closest to the stream 
temperature sites (average $69 \mathrm{~km}$ ) and has the best data series to fit the models and simulate climate change scenarios. When properly chosen, a relatively large distance (up to $244 \mathrm{~km}$ in Mohseni et al. 1998) from the river to the meteorological stations does not negatively affect the strength of the water-air relationship (Pilgrim et al. 1998). Before selecting the data, air temperature data were tested to assess their reliability by applying a homogeneity test. This test is based on a two-sample Kolmogorov-Smirnov test, and it marks years as possibly inhomogeneous data. In a second phase, the marked years are matched against the distribution of the entire series to determine if they have true inhomogeneities, searching for possible dissimilarities between the empirical distribution functions. Consequently, only data before 1955 were discarded.

Water temperature was registered every $2 \mathrm{~h}$ using Hobo ${ }^{\circledR}$ Water Temperature Pro v2 $\left(\right.$ Onset $\left.^{\circledR}\right)$ thermographs located at 11 sites along the altitudinal gradient of the trout range in both streams [six sites in the Cega stream ( $\mathrm{Ct} 1$ to $\mathrm{Ct}$ 6) and five sites in Pirón stream (Pt1 to Pt5) (Figure 1, Table I)] between April 2011 and October 2012. The reaches where the Ct4 and Pt5 thermographs were placed were temporarily dry in 2011.

Electrofishing was conducted at 37 sites [C1 to $\mathrm{C} 25$ sites from 1610 to $730 \mathrm{~m}$ a.s.l. in the Cega stream and P1 to P12 sites from 1620 to $786 \mathrm{~m}$ a.s.l. in the Pirón stream (Figure 1, Table I)] in August for two consecutive years (1997 and 1998) to characterize trout populations. Average distance between consecutive sites was $4.45 \mathrm{~km}$ (range: $0.55-12.06 \mathrm{~km}$ ) at Cega stream and $6.36 \mathrm{~km}$ (range: $2.46-12.30 \mathrm{~km}$ ) at Pirón stream. Density was obtained for trout and the rest of present fish species by means of the maximum weighted likelihood method (Carle and Strub 1978). A severe drought occurred in 1998, and as a result, sites C7, C11, C14, C22, C23, P3 and those downstream of $\mathrm{P} 10$ were dry during the second electrofishing sampling event.
Table I. Altitude of electrofishing sites at Cega stream $(\mathrm{Cn})$ and Pirón stream $(\mathrm{P} n)$.

\begin{tabular}{|c|c|c|c|}
\hline \multicolumn{2}{|c|}{ Cega stream } & \multicolumn{2}{|c|}{ Pirón stream } \\
\hline Site & Altitude & Site & Altitude \\
\hline C1 & 1610 & $\mathrm{P} 1$ & 1620 \\
\hline $\mathrm{C} 2$ & 1320 & $\mathrm{P} 2$ & 1337 \\
\hline C3 & 1258 & P3 & 969 \\
\hline $\mathrm{C} 4$ & 1150 & P4 & 908 \\
\hline C5 & 1106 & P5 & 879 \\
\hline C6 & 1044 & P6 & 858 \\
\hline $\mathrm{C} 7$ & 995 & P7 & 856 \\
\hline $\mathrm{C} 8$ & 966 & P8 & 835 \\
\hline C9 & 961 & P9 & 822 \\
\hline $\mathrm{C} 10$ & 944 & P10 & 810 \\
\hline C11 & 934 & P11 & 804 \\
\hline C12 & 921 & P12 & 786 \\
\hline C13 & 910 & & \\
\hline C14 & 898 & & \\
\hline $\mathrm{C} 15$ & 885 & & \\
\hline C16 & 866 & & \\
\hline $\mathrm{C} 17$ & 845 & & \\
\hline C18 & 805 & & \\
\hline C19 & 798 & & \\
\hline C20 & 788 & & \\
\hline C21 & 780 & & \\
\hline $\mathrm{C} 22$ & 778 & & \\
\hline $\mathrm{C} 23$ & 762 & & \\
\hline $\mathrm{C} 24$ & 748 & & \\
\hline $\mathrm{C} 25$ & 730 & & \\
\hline
\end{tabular}

$n$ is the site number. Unit: $\mathrm{m}$ a.s.l.

Water temperature at the electrofishing time was rebuilt by modelling as explained later. The drought that occurred in 1998 did not negatively affect to study reliability, quite the contrary: drought is a singularity that introduces useful variability to the analysis.

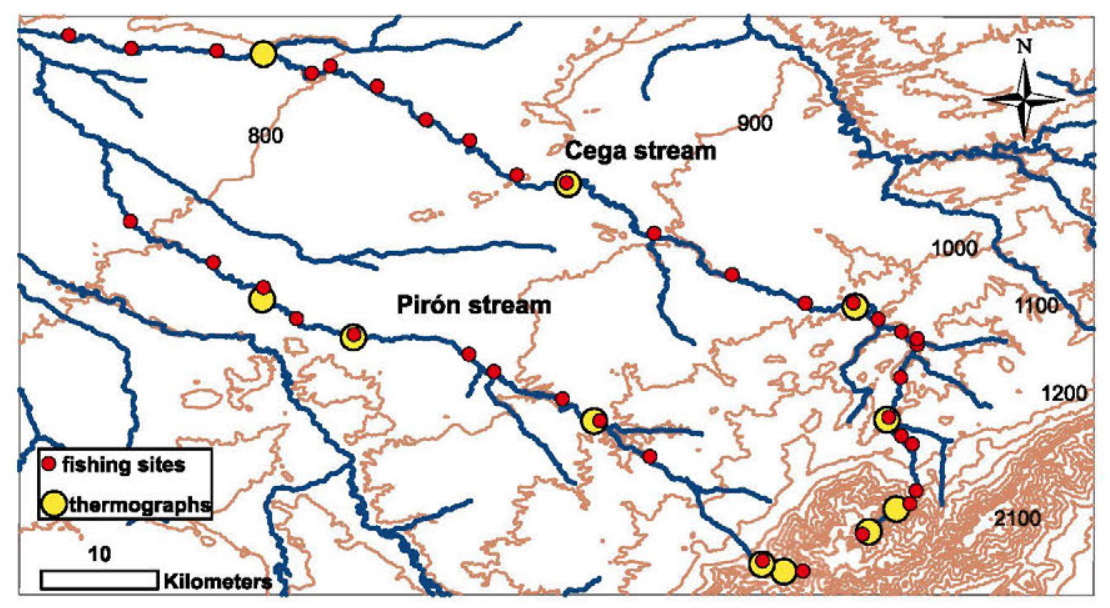

Figure 1. Location map of thermographs and electrofishing sites. Distance between contour lines (altitude above sea level): $100 \mathrm{~m}$. Thermographs are numbered in text from headwaters to downwaters, Ct1 to Ct6 (Cega stream) and Pt1 to Pt5 (Pirón stream). Electrofishing sites are numbered from headwaters to downwaters, C1 to C25 (Cega stream) and P1 to P12 (Pirón stream). 


\section{Climate change modelling and downscaling}

We used data from nine global climate models associated with the 5th Coupled Model Intercomparison Project (Table II). For these models, we used a 'twentieth century' simulation as the control run (the Historical simulation) and two future climate projections corresponding to the Representative Concentration Pathways RCP4.5 (stable scenario) and RCP8.5 (more increasing scenario) (Taylor et al. 2009).

For downscaling, we used a two-step analogue statistical method developed by Ribalaygua et al. (2013). The first step is an analogue approach (Zorita and von Storch 1999) in which the most similar number $(n)$ of days to the day to be downscaled is selected. The similarity between the two days was measured using the pseudo-Euclidean distance between four large-scale fields as predictors: 1 the speed and 2 direction of the geostrophic wind at $1000 \mathrm{hPa}$ and (3) the speed and (4) direction of the geostrophic wind at $500 \mathrm{hPa}$. In the second step, the temperature determination was obtained using a multiple linear regression analysis using the selected $n$ of most analogous days. This was performed for each station and for each problem day, as well as for maximum and minimum temperatures. The linear regression uses forward and backward stepwise selections of the predictors to select only the predictive variables for that particular case.

As a measure of the goodness of the downscaling methodology, Figure 2 shows the monthly average of the maximum and minimum daily air temperatures for the observed data series (1958-2002) and for the simulated maximum and minimum values by downscaling the European Centre for Medium-Range Weather Forecasts ERA-40 re-analysis of daily data (Uppala et al. 2005). Bias and mean absolute error (MAE) were used as goodness indicators, and the means of their monthly averages of maximum values were -0.03 and $1.77^{\circ} \mathrm{C}$, respectively.
The means of the monthly averages of minimum values were -0.05 and $1.88^{\circ} \mathrm{C}$, respectively. These values represent very good values, particularly for MAE, if we consider that the attributable error to the meteorological stations is approximately $1^{\circ} \mathrm{C}$.

A systematic error is obtained when comparing the simulated data from climate models with the observed data from reference time series due to the inherent downscaling methodology error and to the inner global climate model error (which usually introduce a bias over the data). To correct this systematic error, the future climate projections were corrected according to a parametric quantile-quantile method (Monjo et al. 2014). This was performed by comparing the observed and projected empirical cumulative distribution functions (ECDFs), linking them by the ECDF of the downscaled ERA-40.

As a consequence, daily maximum and minimum temperatures for the Ataquines meteorological station were obtained for each climate change scenario. From these temperatures, daily mean temperatures were obtained and used as an input to simulate climate change scenario effects on the Cega and Pirón streams. Figure 3 shows the quarterly increasing trends of simulated daily mean air temperature (DMAT).

\section{Stream temperature modelling}

Modelling was necessary to rebuild the stream thermal data because stream temperature measurements and fishing samplings did not overlap in time. Water temperature follows air temperature with a small time lag. Therefore, weekly moving average stream temperature is often used for this purpose because it usually exhibits a better correlation than the daily average (Stefan \& Preud'homme 1993). On the other hand, the established time for determining thermal tolerance is usually 7 consecutive

Table II. The nine CMIP5 climate models used in this study

\begin{tabular}{|c|c|c|c|}
\hline Model & Institution & Country & Resolution (lon $\times$ lat) \\
\hline BCC-CSM1-1 & Beijing Climate Center (BCC), China Meteorological Administration & China & $2.8 \times 2.8^{\circ}$ \\
\hline CanESM2 & Canadian Centre for Climate Modelling and Analysis (CC-CMA) & Canada & $2.8 \times 2.8^{\circ}$ \\
\hline CNRM-CM5 & $\begin{array}{l}\text { Centre National de Recherches Meteorologiques/Centre Europeen } \\
\text { de Recherche et Formation Avancees en Calcul Scientifique } \\
\text { (CNRM-CERFACS) }\end{array}$ & France & $1.4 \times 1.4^{\circ}$ \\
\hline GFDL-ESM2 M & Geophysical Fluid Dynamics Laboratory (GFDL) & United States & $2 \times 2.5^{\circ}$ \\
\hline HADGEM2-CC & Met Office Hadley Centre (MOHC) & UK & $1.87 \times 1.25^{\circ}$ \\
\hline MIROC-ESM-CHEM & $\begin{array}{l}\text { Japan Agency for Marine-Earth Science and Technology } \\
\text { (JAMSTEC), Atmosphere and Ocean Research Institute } \\
\text { (AORI), and National Institute for Environmental } \\
\text { Studies (NIES) }\end{array}$ & Japan & $2.8 \times 2.8^{\circ}$ \\
\hline MPI-ESM-MR & Max Planck Institute for Meteorology (MPI-M) & Germany & $1.8 \times 1.8^{\circ}$ \\
\hline MRI-CGCM3 & Meteorological Research Institute (MRI) & Japan & $1.2 \times 1.2^{\circ}$ \\
\hline NorESM1-M & Norwegian Climate Centre (NCC) & Norway & $2.5 \times 1.9^{\circ}$ \\
\hline
\end{tabular}

More details can be found in http://cmip-pcmdi.llnl.gov/cmip5/ 


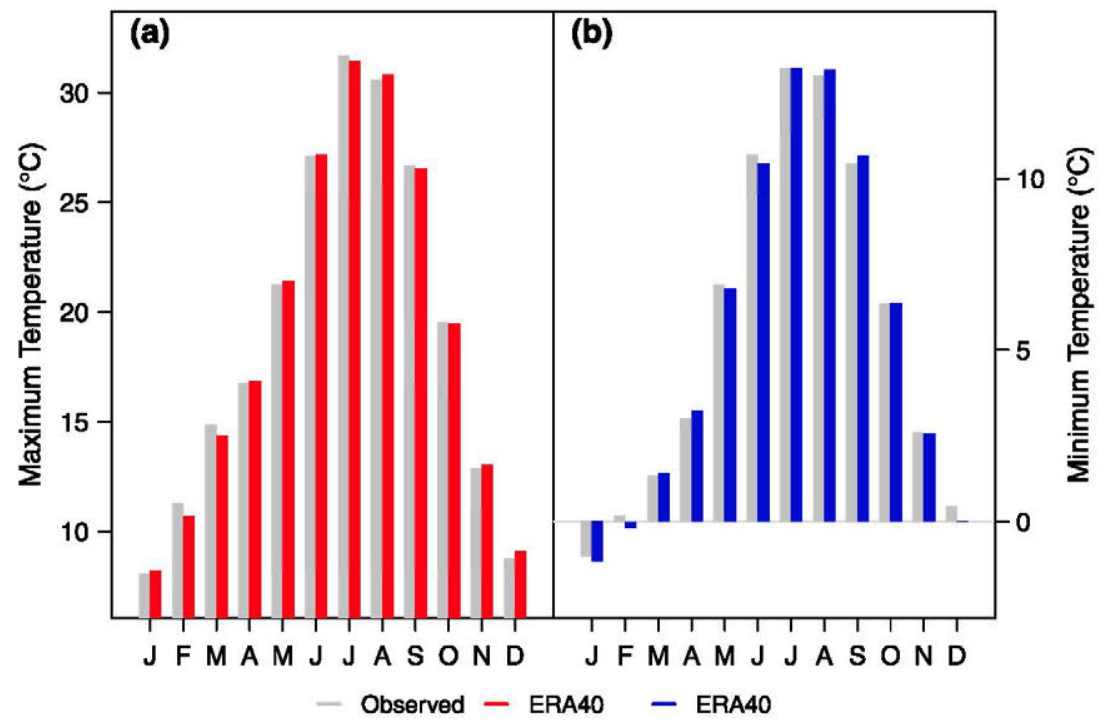

Figure 2. Monthly average of (a) maximum and (b) minimum daily air temperatures for the observed data series (1958-2002) and for the simulated maximum and minimum values by downscaling of the ERA-40 re-analysis.

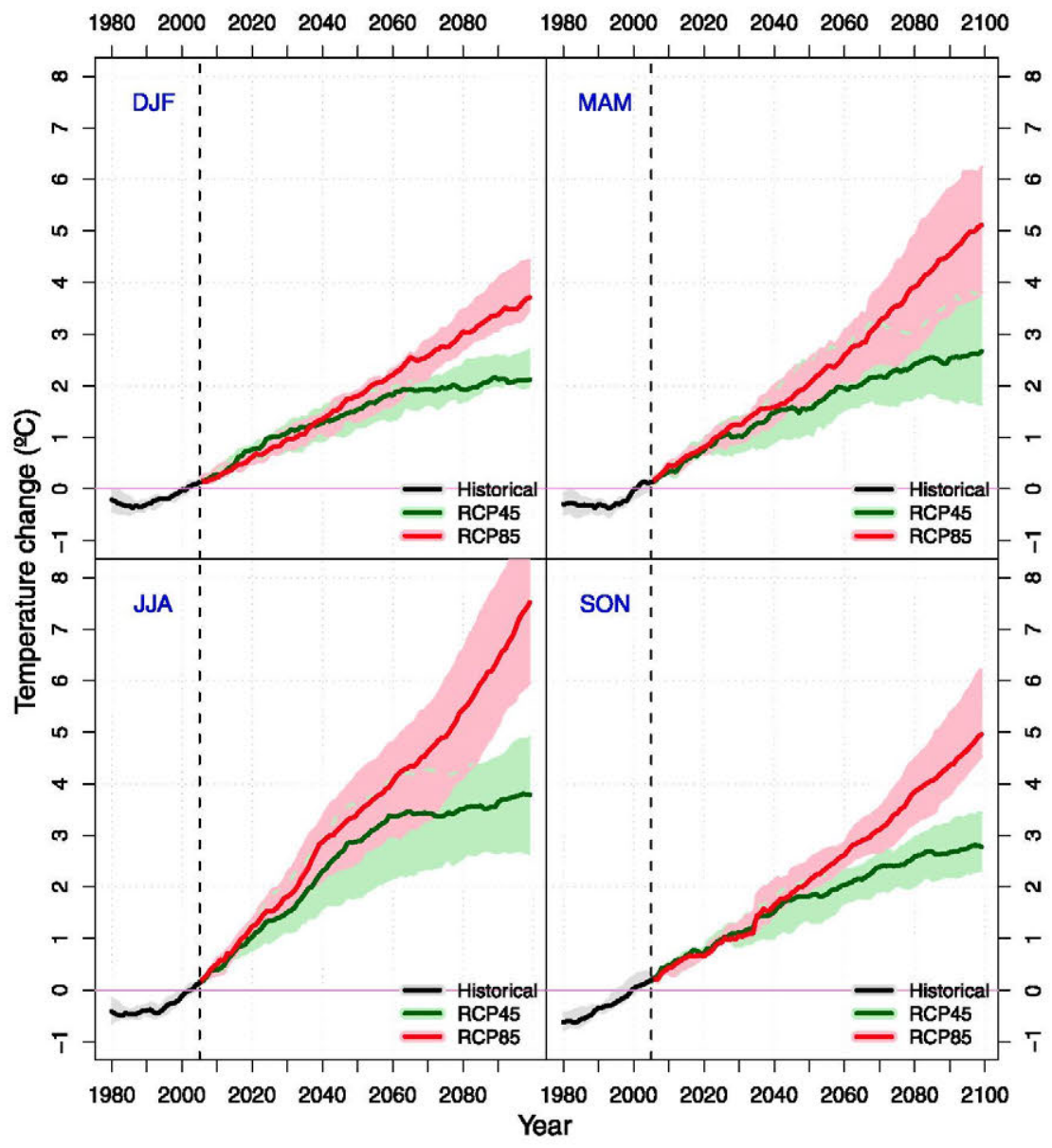

Figure 3. Expected relative seasonal increases in daily mean temperature throughout the 21 st century (as 30 -year moving averages) for the two studied RCPs (RCP4.5 and RCP8.5) against the 1971-2000 average (used as a reference). The vertical dotted line indicates the end of the historical experiment (black) and the start of the (November) RCPs. Thick lines show the median of the values for all models; the shaded area indicates ranges from the 10th to 90th percentiles. Seasons are indicated by their months: (a) winter (December, January, February); (b) spring (March, April, May); (c) summer (June, July, August); (d) autumn (September, October). 
days (Elliott and Elliott 2010). However, using the weekly moving average could introduce errors such as the overestimation of the importance of a threshold because a determined weekly moving average does not indicate that every considered daily average was equal to or higher than the weekly moving average. Consequently, daily mean temperature was used in this study because it better reflects the average conditions that trout must experience for an extended period. In addition, studying events of 7 consecutive days above a daily mean threshold was preferred over using the 7-day moving average because it better reflects when a threshold is exceeded. We therefore needed to improve the correlation between air and water daily temperatures and used a modification of the Mohseni et al. (1998) model to accomplish this. This modified model includes a trajectory of temperature by adding the product of the daily increase in daily mean temperature and a parameter reflecting the resistance of water temperature to change.

The original Mohseni et al. 1998 model is as follows:

$$
T_{s}=\mu+\frac{\alpha-\mu}{1+e^{\gamma\left(\beta-T_{a}\right)}}
$$

where $T_{s}$ is daily mean stream temperature (DMST), $T_{a}$ is DMAT, $\mu$ is the estimated minimum stream temperature, $\alpha$ is the estimated maximum stream temperature, $\beta$ represents the air temperature at which the rate of change of the stream temperature with respect to the air temperature is at a maximum and $\gamma$ is the value of the rate of change at $\beta$.

The introduced trajectory component modifies the model to

$$
T_{s}=\mu+\frac{\alpha-\mu}{1+e^{\gamma\left(\beta-T_{a}\right)}}+\lambda\left(\Delta T_{a}\right)
$$

where $\lambda$ is a coefficient representing the resistance of DMST to change with respect to DMAT variation in one day $\left(\Delta T_{a}\right)$.

Nonlinear regression was used to estimate the parameters of the models, and bootstrap techniques were used to consider the autocorrelation effect on the parametric signification (Freedman and Peters 1984). Calculations were performed using R software ( $\mathrm{R}$ Core Team 2013). A 95\% confidence interval was calculated for each parameter. Bayesian information criterion (BIC), Akaike information criterion (AIC) and root mean square error (RMSE) were used to test the modified model.

High correlation was detected between the annual average of DMST and altitude in both streams $\left(R^{2}=0.986\right.$ and 0.985). Thus, altitudinal interpolation of the model parameters was performed to determine the values of the estimated parameters at each electrofishing site; altitudinal extrapolation was performed for the $\mathrm{C} 23, \mathrm{C} 24$ and $\mathrm{C} 25$ sites in the Cega stream and for the P11 and P12 sites in the Pirón stream. A digital elevation model [DEM at a $5-\mathrm{m}$ resolution, obtained from LIDAR, IGN (National Geographic Institute of the Spanish Government)] was used for modelling stream temperature as a continuum. Thus, the obtained models were used to study the electrofishing sites with the different sampling dates and climate change scenarios. Thereby, it was possible to reflect thermal heterogeneity, and the proportion of thermal habitat loss was determined continuously all along the stream with high spatial resolution. $\operatorname{ArcGis}^{\circledR} 10.1$ (by ESRI $^{\circledR}$ ) was used to manage the DEM.

\section{Thermal threshold determination}

The number of days that exceeded different thresholds of daily mean temperature at electrofishing sites between 1997 and 1998 was quantified. The number of times that the thresholds were exceeded for 7 consecutive days and the maximum consecutive days above those thresholds were also quantified to determine the exclusion temperature. Thresholds were analysed with $0 \cdot 1{ }^{\circ} \mathrm{C}$ of resolution. The ability of these thresholds to forecast the presence/absence of trout was tested by means of Hanssen-Kuiper criterion (HK) (McBride and Ebert 2000). Ideally, HK requires the same positive and negative true scores, such that any deviation will influence the final value. Thus, we selected the highest relative value of $\mathrm{HK}$ to identify the best forecaster of the trout distribution boundary. We also calculated the BIAS (McBride and Ebert 2000), hit ratio (h.r.) and standard deviation (s.d.) to assess the selection.

Analysis of DMST, daily maximum stream temperature and their 7-day moving average supported the choice of threshold criteria (Appendix A).

\section{Other niche traits}

In addition to temperature, other constraints define the brown trout realized niche (e.g. Armstrong et al., 2003). The predictive capacity of chemical, physical, hydrological and biological traits was analysed by means of three methods: $t$-test, generalized linear models (GLM, significance level: $0 \cdot 1$ ) and receiver operating characteristic curve (ROC). Then, these traits were compared against temperature variables (times above the threshold during 7 days or more, values of the model parameters for each fishing site) to rank their relative importance as predictors of the presence/absence of trout. The analysed variables were as follows: chemical components (oxygen, phosphorus, nitrogen, conductivity, pH), BMWP' quality index (AlbaTercedor and Sánchez-Ortega 1988), substrate composition (classes' frequency), mean discharge of the previous month $\left(\mathrm{hm}^{3}\right)$, channel slope and width, and density of each one of the species of the fish community.

\section{RESULTS}

\section{Trout presence}

Brown trout were not detected downstream from $\mathrm{C} 24$ in the Cega stream or from P8 in the Pirón stream. Trout were 
also absent in intermediate $\mathrm{C} 14$ and $\mathrm{P} 3$ sites in the first year, whereas in $\mathrm{C} 15$, only one trout was captured each year. In C24, one trout was caught in the first sampling, and six trout were caught in the second sampling. The catches at sampling sites downstream of C18 were not homogeneous between 1997 and 1998 because catches occurred in only one of the two sampling events in these sites, with the exception of $\mathrm{C} 20$. Although the Pirón stream is a tributary of the Cega stream, the trout populations of both streams are not connected to each other.

The altitudinal lower limits of the brown trout range were located at approximately $730 \mathrm{~m}$ a.s.l. in the Cega stream and at $820 \mathrm{~m}$ a.s.l. in the Pirón stream at the time of sampling.

\section{Stream temperature}

The thermographs recorded 544 days of data (with the exception of Ct4: 407 days, Ct6: 501 days, Pt2: 483 days and Pt5: 424 days) (Supporting Information S1). All the estimated parameters of the stream temperature models were significant $(p<0.025)$, and the proposed modified model showed better values for AIC, RMSE and BIC than the Mohseni et al. (1998) model when DMST is used (Table III). The RMSE average for thermal samples ranged from 1.08 to $1.93{ }^{\circ} \mathrm{C}$. Only the Pt2 (1335 m a.s.l.) and Pt3 ( $905 \mathrm{~m}$ a.s.1.) sites showed anomalous thermal behaviour, but the values were within the RMSE range. The Torrecaballeros dam is altering the natural thermal regime upstream of the Pt2 site (Santiago et al. 2013), which causes difficulty in modelling. Drainage by spillways of the heated water by solar radiation at the beginning of spring is postulated as responsible for fast increase in temperature of the water under the dam at that time. Snow-melting homogenized again the water temperature, after which the increasing temperature trend returns. When in the transition from spring to summer the water level descends, drainage is done by the bottom drainage and the outlet temperature decreases. Torrecaballeros reservoir is relatively small, and when water level drops at summer, hypolimnetic and epilimnetic water mixed and heated quickly. Then, water drainages by the bottom are very much warmer than if there was no reservoir. In addition, a spring and a catchment for drinking water produced an anomalous performance of thermal models near the Pt 3 site by smoothing the expected temperature oscillations and altering the thermal flux in dependence on the quantity of abstracted water.

\section{Thermal threshold determination}

The brown trout thermal boundaries (1997-1998) were determined by the absence of trout and the occurrence of events of 7 or more consecutive days (henceforth c.d.) above $18.7^{\circ} \mathrm{C}$ DMST in Cega ( $\mathrm{HK}=0.524$, BIAS $=0.881$, h.r. $=0.844$, s.d. $=0.131)$ and above $18.1{ }^{\circ} \mathrm{C}$ in Pirón $(H K=0.857$, BIAS $=1.071$, h.r. $=0.952$, s.d. $=0.045$ ) at the time of sampling. The results of Pirón show a threshold band between 17.2 and $18.1^{\circ} \mathrm{C}$, but the latter was chosen because the stream temperature change ratio is insignificant above $17.2^{\circ} \mathrm{C}$ at the border of the observed trout range; otherwise, the threshold could be underestimated. These observed thresholds are lower than the critical feeding temperature for this species (between 19.4 and $26.8^{\circ} \mathrm{C}$, in Elliott and Elliott 2010).

The number of days per year above the different thresholds (DAT), the number of times per year above the 7 or more c.d. threshold (TAT $\geq 7$ ) and the maximum c.d. per year above the thresholds (MCDAT) are shown in Table IV.

\section{Other niche traits}

GLM analyses showed that $73-88 \%$ of the deviation of trout density (global and stratified by age classes) was explained by linear models using hydrological, substrate and temperature-related variables as predictors.

Table III. Akaike information criterion (AIC), root mean square error (RMSE) and Bayesian information criterion (BIC) values for daily mean stream temperature models with four and five parameters (Mohseni et al. 1998 model and modified model in this study, respectively).

\begin{tabular}{|c|c|c|c|c|c|c|}
\hline \multirow[b]{2}{*}{ Thermograph } & \multicolumn{2}{|c|}{$\mathrm{AIC}$} & \multicolumn{2}{|c|}{ RMSE } & \multicolumn{2}{|c|}{$\mathrm{BIC}$} \\
\hline & Four parameters & Five parameters & Four parameters & Five parameters & Four parameters & Five parameters \\
\hline $\mathrm{Ct} 1$ & $1866 \cdot 5$ & 1794.8 & 1.914 & 1.292 & 1887.9 & $1820 \cdot 5$ \\
\hline $\mathrm{Ct} 2$ & 1935.9 & $1848 \cdot 6$ & $2 \cdot 217$ & $1 \cdot 359$ & $1957 \cdot 3$ & $1874 \cdot 3$ \\
\hline Ct3 & $2138 \cdot 5$ & $2084 \cdot 3$ & $3 \cdot 508$ & 1.695 & 2204.9 & $2109 \cdot 9$ \\
\hline $\mathrm{Ct} 4$ & $1436 \cdot 3$ & 1337.9 & $2 \cdot 179$ & 1.296 & $1456 \cdot 2$ & $1361 \cdot 8$ \\
\hline $\mathrm{Ct} 5$ & $1743 \cdot 6$ & $1605 \cdot 7$ & $1 \cdot 544$ & 1.082 & $1765 \cdot 0$ & $1631 \cdot 4$ \\
\hline Ct6 & $1920 \cdot 9$ & $1825 \cdot 5$ & $2 \cdot 936$ & $1 \cdot 544$ & 1941.9 & $1850 \cdot 7$ \\
\hline Pt1 & $1771 \cdot 0$ & $1701 \cdot 4$ & 1.611 & $1 \cdot 184$ & $1792 \cdot 4$ & $1727 \cdot 1$ \\
\hline $\mathrm{Pt} 2$ & $1988 \cdot 2$ & 1965.4 & 3.929 & 1.920 & $2009 \cdot 0$ & $1990 \cdot 4$ \\
\hline Pt3 & $1625 \cdot 0$ & $1606 \cdot 4$ & $1 \cdot 221$ & 1.083 & $1646 \cdot 4$ & $1632 \cdot 1$ \\
\hline Pt4 & $1768 \cdot 1$ & $1650 \cdot 1$ & 1.593 & $1 \cdot 128$ & $1789 \cdot 5$ & 1675.8 \\
\hline Pt5 & $1581 \cdot 3$ & $1092 \cdot 0$ & $2 \cdot 428$ & $1 \cdot 267$ & $1601 \cdot 6$ & $1114 \cdot 8$ \\
\hline
\end{tabular}


Table IV. Number of days per year above the different thresholds (DAT), number of times per year above the thresholds during 7 or more consecutive days (TAT $\geq 7$ ) and the maximum number of consecutive days per year above the thresholds (MCDAT) in each location for the sampling years.

\begin{tabular}{|c|c|c|c|}
\hline & DAT & $\mathrm{TAT} \geq 7$ & MCDAT \\
\hline Location & 1997 & 1998 & 1997 \\
\hline
\end{tabular}

$18.7^{\circ} \mathrm{C}$

$\mathrm{C} 1$

$\mathrm{C} 2$

C3

$\mathrm{C} 4$

$\mathrm{C} 5$

C6

C7

$\mathrm{C} 8$

C9

$\mathrm{C} 10$

C11

$\mathrm{C} 12$

$\mathrm{C} 13$

C14

C15

C16

C17

C18

C19

$\mathrm{C} 20$

C21

$\mathrm{C} 22$

C23

C24

$\mathrm{C} 25$

$18 \cdot 1^{\circ} \mathrm{C}$

P1

P2

P3

P4

P5

P6

P7

P8

P9

P10

P11

P12

$\begin{array}{rc}1 & 10 \\ 12 & 14 \\ 20 & 25 \\ 16 & 20 \\ 10 & 14 \\ 8 & 12 \\ 1 & 11 \\ 1 & 8 \\ & 4\end{array}$

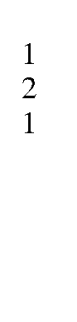

1
1
1

$\begin{array}{rl}1 & 6 \\ 7 & 7 \\ 10 & 8 \\ 9 & 8 \\ 3 & 6 \\ 3 & 6 \\ 1 & 6 \\ 1 & 5 \\ & 4\end{array}$

Thresholds: $18.7^{\circ} \mathrm{C}$ in Cega and $18.1^{\circ} \mathrm{C}$ in Pirón.

Specifically, GLM model including community structure explained $17 \%$ of deviance (AIC 437.98) of the total density. Models using average flow of July, temperature variables and substrate explained 69\% (AIC 379.09), 78\% (AIC 367.34) and 81\% (AIC 361.60), respectively. A GLM model containing all these potential predictors showed lower AIC scores (341.51, explained deviance: $86 \%$ ) than models including only one type of variables. Similarly, $44 \%$ of deviance of $3++$ trout density was explained by community structure (AIC 398.68) and $37 \%$ by temperature (AIC 407.07). GLM of age class 3++ with all types of variables yields $68 \%$ of explained deviance (AIC 382.80). Age class $3++$ is the most abundant in the lower part of the trout distribution in these streams (Junta de Castilla y León, 1997) and was considered the best age class to be used for the threshold determinations.

Results of the ROC analysis showed that the only reliable predictor was $\mathrm{TAT} \geq 7$. This predictor exhibited an area under the curve of 0.84; when density influence was studied instead of presence/absence, area under the curve was 1.0 (the best result). The density of other species was not as reliable.

Finally, the results of $t$-test (Bonferroni correction) are consistent with the results showing $\mathrm{TAT} \geq 7$ as the only reliable predictor $(p=1 \cdot 3 \mathrm{e}-5)$.

\section{Climate change}

The observed thresholds $\left(18.7^{\circ} \mathrm{C}\right.$ in Cega and $18.1{ }^{\circ} \mathrm{C}$ in Pirón) were studied for the climate change scenarios. The frequency of higher DMST than the observed thresholds increased with time in both scenarios. As expected, this frequency was significantly higher in RCP8.5 than in RCP4.5 (Figure 4). The frequency of longer intervals (7 or more days, Figure 5) of high temperatures increased in the same way, which reached a maximum of $56 \mathrm{c.d}$. in the C6, $\mathrm{C} 7$ and $\mathrm{C} 25$ sites at $18.7^{\circ} \mathrm{C}$ in RCP8.5. In the P11 and P12 sites, the maximum was 59 c.d. at $18.1{ }^{\circ} \mathrm{C}$ in the same scenario (Figure 6).

The decadal average (period 2090-2099) of the DAT, TAT $\geq 7$ and MCDAT was modelled in each sampling site for each climate change scenario (Table V). The results at the Cega stream demonstrate that the DAT increased 4.0 times (average value) in RCP4.5 and 13.9 times in RCP8.5. The TAT $\geq 7$ increased 2.4 times in RCP4.5 and 2.9 times in RCP8.5. The MCDAT increased 3.0 times in RCP4.5 and 9.2 times in RCP8.5. At the Pirón stream, the average values were as follows: DAT, 5.6 times in RCP4.5 and 8.5 times in RCP8.5; TAT $\geq 7,1.8$ times in RCP4.5 and 2.0 times in RCP8.5; MCDAT, 4.5 times in RCP4.5 and 7.3 times in RCP8.5.

The RCP4.5 scenario forecasts that 7 c.d. above the thresholds will occur at $785 \mathrm{~m}$ a.s.l. (Cega stream) and $830 \mathrm{~m}$ a.s.1. (Pirón stream); in the RCP8.5 scenario, these altitudes will be at $830 \mathrm{~m}$ a.s.l. and $831 \mathrm{~m}$ a.s.l., averaged over forecasts for the 2090-2099 period. A warm window in the intermediate reach characterized by the $\mathrm{Ct} 3$ site (1043 m a.s.1.) in Cega would also open as a consequence of climate change. In this sense, warmer waters could extend to $941 \mathrm{~m}$ a.s.l. (RCP4.5) or $913 \mathrm{~m}$ a.s.l. (RCP8.5) downstream. The upstream boundary of this window was associated with a water infiltration area beginning at approximately $1050 \mathrm{~m}$ a.s.l. and continuing downstream. 


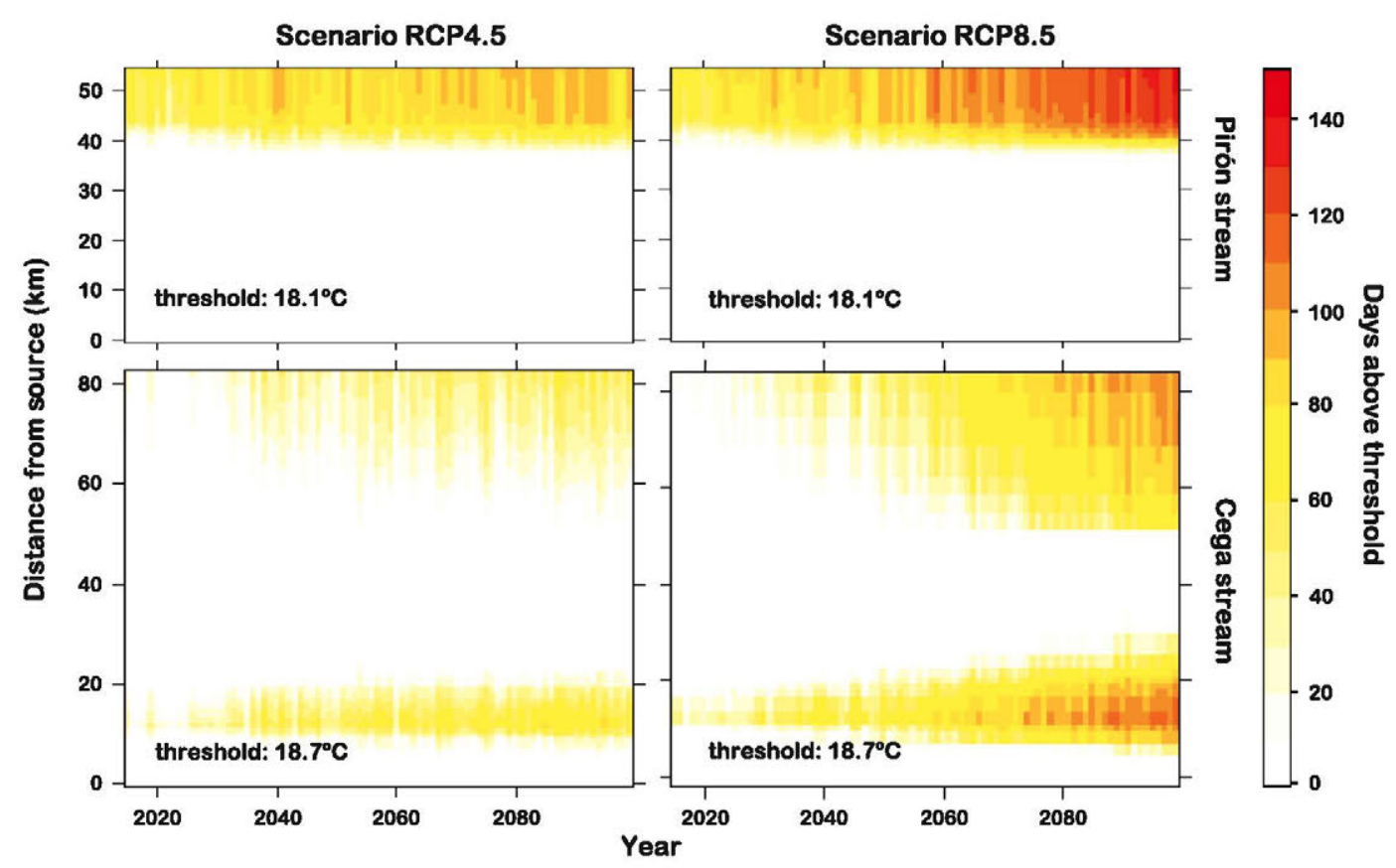

Figure 4. Forecast of the number of days above thermal thresholds up to the year 2099 along the fluvial continuum in the Cega and Pirón streams. Threshold: 18.7 and $18.1^{\circ} \mathrm{C}$ in the Cega and Pirón streams, respectively. Scenarios for RCP 4.5 and 8.5 are shown. Graphic resolution: $1 \mathrm{~km}$.
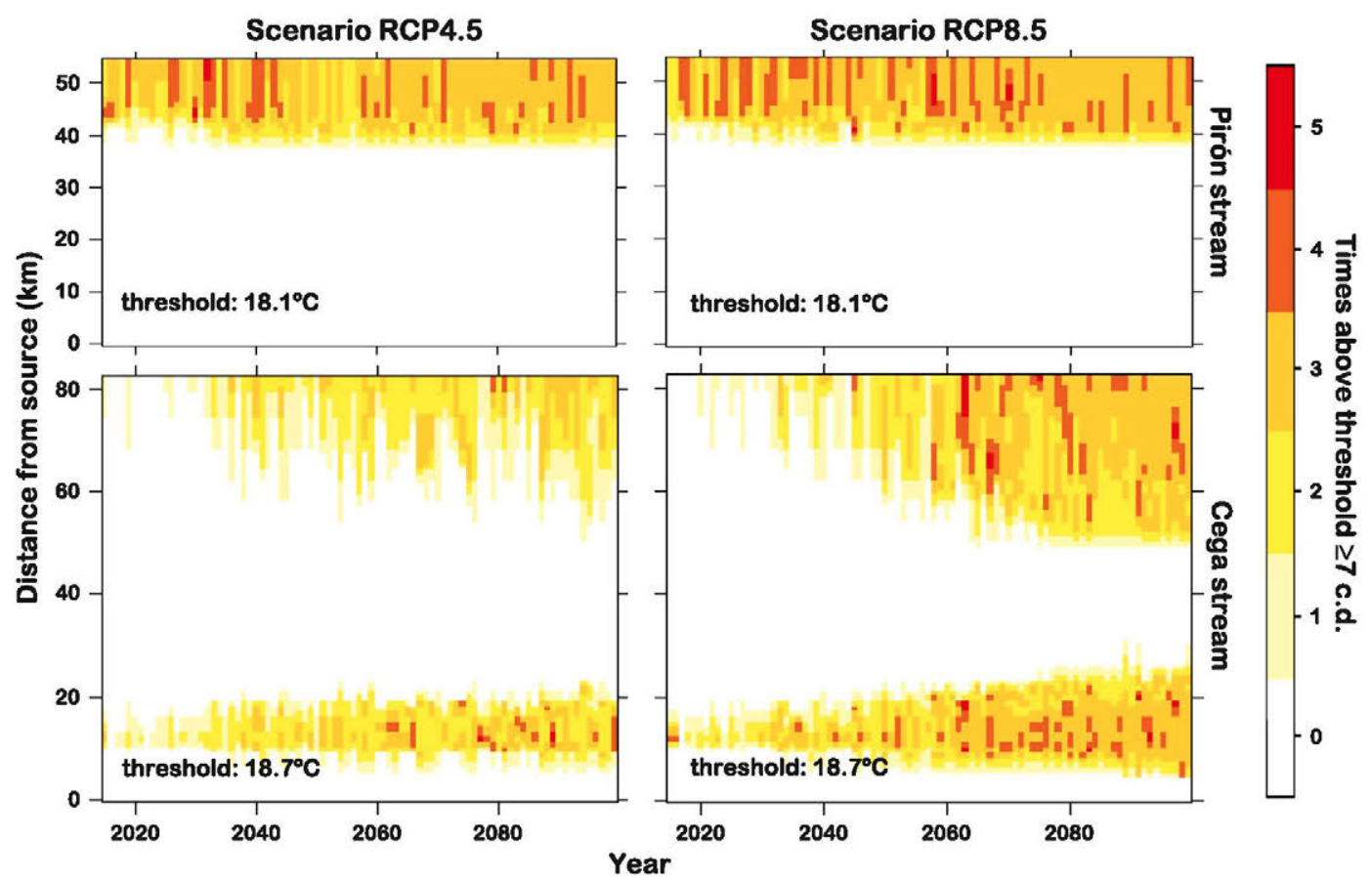

Figure 5. Forecast of the times that the thresholds exceeded 7 or more consecutive days (c.d.) up to the year 2099 along the fluvial continuum in the Cega and Pirón streams. Threshold: 18.7 and $18.1^{\circ} \mathrm{C}$ in the Cega and Pirón streams, respectively. Scenarios RCP 4.5 and 8.5 are shown. Graphic resolution: $1 \mathrm{~km}$.

\section{DISCUSSION}

Daily mean temperature models were accurate enough to be used in rebuilding and forecasting water temperatures from air temperatures. Thus, high reliability was possible for determining the thermal performance of Cega and
Pirón streams. Differences between 1997 and 1998 flow regimes introduced a useful variability for the analysis. On the other hand, the high spatial density of data of fish populations and physical habitat variables allowed inferences to be reliable in spite of the relatively short time series data. 


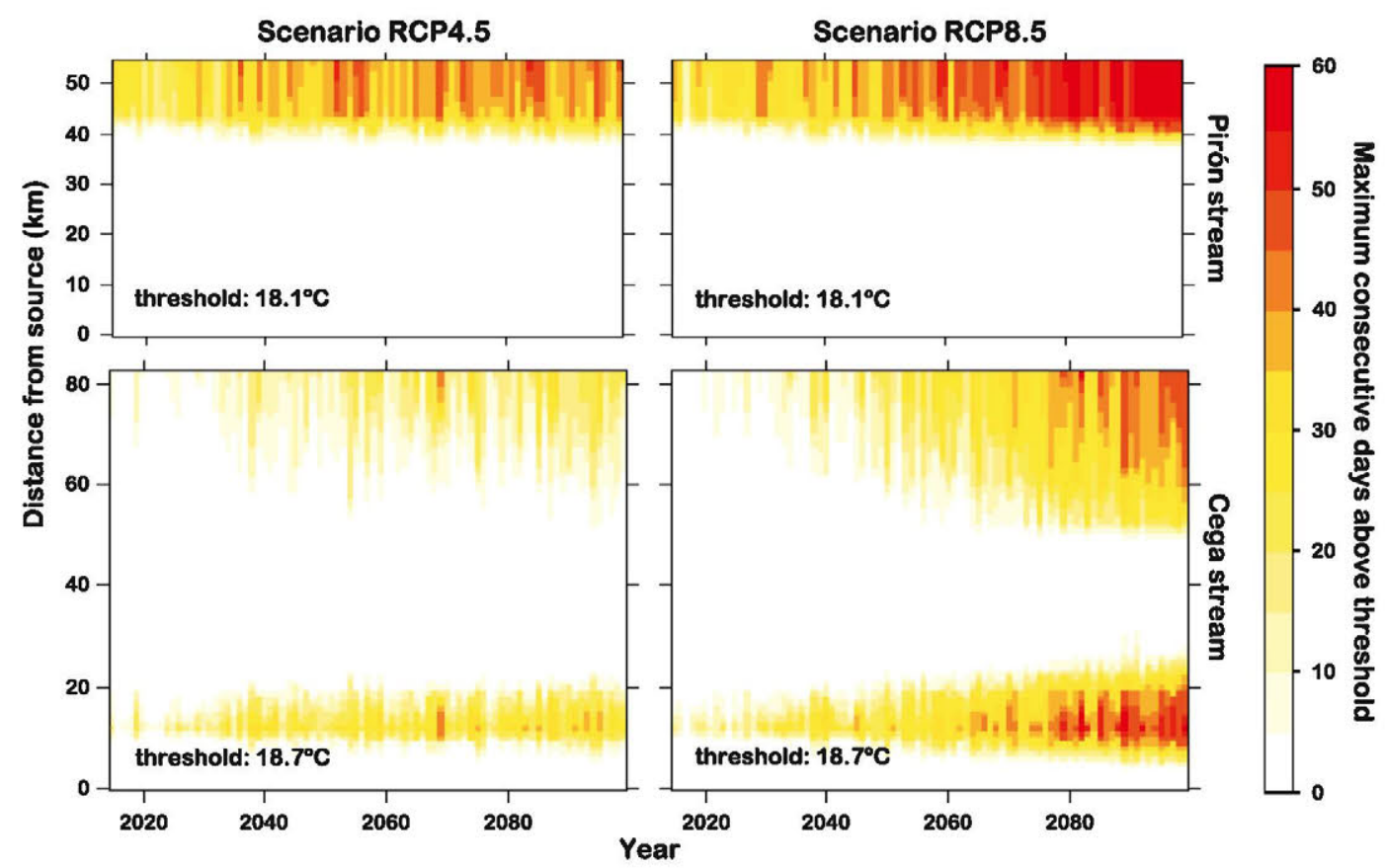

Figure 6. Forecast of the maximum number of consecutive days above thresholds up to the year 2099 along the fluvial continuum in the Cega and Pirón streams. Threshold: 18.7 and $18.1^{\circ} \mathrm{C}$ in the Cega and Pirón streams, respectively. Scenarios RCP 4.5 and 8.5 are shown. Graphic resolution: $1 \mathrm{~km}$.

The temperature threshold of presence/absence can be influenced by the community composition, reducing the thermal realized niche of trout in these streams. It is known that brown trout and Arctic char (Salvelinus alpinus) share spatial and trophic niches coexisting or excluding each other in function of other environmental characteristics (system productivity, temperature - Finstad et al. 2011). The combination of temperature and competition to determine distribution is also known in other ectothermic groups, as lizards (Buckley and Roughgarden, 2006). The River Cega basin populations are living in the southern edge of the brown trout distribution, and they share the space with cyprinids (Iberian barbel Luciobarbus bocagei, Northern Iberian chub Squalius carolitertii) that may compete with it for space and trophic resources in the lower reaches, where cyprinids are more efficient than trout. Sánchez-Hernández and Cobo (2011) found important diet overlap values in sympatry between these species. These authors suggest that 'differences in macrohabitat use, drift behaviour of prey and prey size are important adaptive features that may reduce the inter-specific competition in the fish community and permit the food partitioning that allows coexistence'. Nonetheless, community structure is long known as a determinant of the species abundance (e.g. Tokeshi, 1993). Other environmental variables (hydraulics, temperature) also influence the density of fish populations (Ayllón et al. 2013).

The study of habitat variables showed that temperature (TAT $\geq 7$ days) was the most reliable predictor for trout presence/absence. In agreement with this, the observed limits of the summer distribution of brown trout were linked to DMST thresholds between 18.1 and $18.7^{\circ} \mathrm{C}$. These limits were lower than the critical feeding temperature for brown trout as given by Elliott et al. (1995) $\left(19 \cdot 4^{\circ} \mathrm{C}\right.$ ) and Forseth et al. (2009) (at least $23^{\circ} \mathrm{C}$ ), as well as the upper critical temperature range $\left(20-30^{\circ} \mathrm{C}\right.$, ultimate lethal temperature: $29.7^{\circ} \mathrm{C} / 10 \mathrm{~min}$, in Elliott 2000) and the incipient lethal temperature $\left(24.7^{\circ} \mathrm{C}\right.$ up to 7 days, Elliott 1981). The upper thermal limit found by Hari et al. (2006) using sinusoidal regression was $20 \cdot 0^{\circ} \mathrm{C}$. Competitive interactions are known to influence the realized niche thresholds (Finstad et al. 2011; Fey and Herren, 2014). Thus, relatively high temperatures may be related to long periods of physiological inefficiency, which make trout less competitive for space and may favour its exclusion from warmer sites. However, the observed limits may be influenced by other constraints such as low summer flow, which could reduce the suitable habitat (Wenger et al. 2011). In this sense, we observed very low flow downstream of the P5 site $(879 \mathrm{~m}$ a.s.l.) in the Pirón stream in summer. Water quality was discarded as a significant driver of the distribution as there are no significant differences in either physical-chemical parameters or the index value BMWP' (Alba-Tercedor and Sánchez-Ortega 1988) between sampling sites with and without trout (Junta de Castilla y León, 1997).

Moreover, we estimated high summer temperatures (up to $20^{\circ} \mathrm{C}$ but less than 7 c.d.) in the piedmont zone, coinciding with karst geology, which supports a healthy trout population. Subsurface infiltration occurs in the karst 
Table V. Decadal average (2090-2099) of the number of days per year above the different thresholds (DAT), number of times per year above the thresholds during 7 or more consecutive days (TAT $\geq 7$ ) and the maximum number of consecutive days per year above the thresholds (MCDAT) modelled in each survey location.

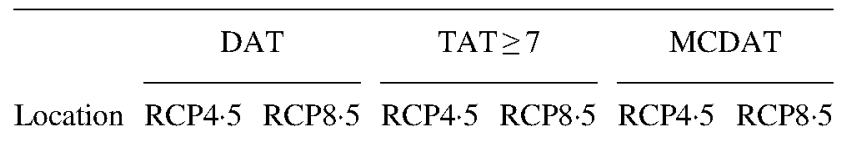

\begin{tabular}{|c|c|c|c|c|c|c|}
\hline \multicolumn{7}{|c|}{$18.7^{\circ} \mathrm{C}$} \\
\hline $\mathrm{C} 2$ & & $0 \cdot 1$ & & & & $0 \cdot 1$ \\
\hline C3 & 0.3 & $33 \cdot 4$ & & 1.4 & 0.3 & $10 \cdot 6$ \\
\hline $\mathrm{C} 4$ & $30 \cdot 0$ & $87 \cdot 8$ & 1.6 & 2.9 & 14.4 & $40 \cdot 5$ \\
\hline C5 & 49.0 & 97.8 & 2.6 & 3 & $21 \cdot 8$ & 44.8 \\
\hline C6 & $69 \cdot 3$ & $108 \cdot 0$ & $2 \cdot 6$ & $3 \cdot 3$ & $30 \cdot 8$ & $49 \cdot 7$ \\
\hline $\mathrm{C} 7$ & $60 \cdot 1$ & 103.4 & $2 \cdot 5$ & $3 \cdot 2$ & $28 \cdot 8$ & $45 \cdot 7$ \\
\hline $\mathrm{C} 8$ & 46.0 & $96 \cdot 2$ & $2 \cdot 3$ & $3 \cdot 1$ & $18 \cdot 2$ & $43 \cdot 7$ \\
\hline C9 & 41.7 & 93.6 & 2 & $3 \cdot 1$ & $17 \cdot 1$ & $41 \cdot 3$ \\
\hline $\mathrm{C} 10$ & $25 \cdot 6$ & $84 \cdot 1$ & 1 & 3 & 10 & $34 \cdot 1$ \\
\hline $\mathrm{C} 11$ & $15 \cdot 2$ & $75 \cdot 0$ & 0.6 & $2 \cdot 5$ & $5 \cdot 2$ & 29.8 \\
\hline $\mathrm{C} 12$ & $5 \cdot 3$ & 58.0 & & $2 \cdot 2$ & 1.9 & $17 \cdot 6$ \\
\hline $\mathrm{C} 13$ & 0.8 & $30 \cdot 7$ & & $0 \cdot 2$ & & $5 \cdot 5$ \\
\hline $\mathrm{C} 14$ & $0 \cdot 1$ & $5 \cdot 9$ & & & $0 \cdot 1$ & 1.4 \\
\hline $\mathrm{C} 15$ & & $0 \cdot 1$ & & & & $0 \cdot 1$ \\
\hline \multicolumn{7}{|l|}{$\mathrm{C} 16$} \\
\hline $\mathrm{C} 17$ & & $0 \cdot 1$ & & & & $0 \cdot 1$ \\
\hline C18 & $8 \cdot 3$ & $67 \cdot 1$ & $0 \cdot 1$ & $2 \cdot 6$ & $3 \cdot 2$ & 25.6 \\
\hline C19 & $12 \cdot 2$ & 73.4 & 0.4 & 2.7 & 4.4 & $29 \cdot 7$ \\
\hline $\mathrm{C} 20$ & $20 \cdot 9$ & 81.7 & 0.9 & $2 \cdot 6$ & $8 \cdot 2$ & 33.7 \\
\hline $\mathrm{C} 21$ & 27.9 & $86 \cdot 4$ & $1 \cdot 2$ & $3 \cdot 2$ & $11 \cdot 2$ & $36 \cdot 5$ \\
\hline $\mathrm{C} 22$ & $29 \cdot 6$ & $87 \cdot 0$ & 1.5 & 3 & 11.9 & 38 \\
\hline $\mathrm{C} 23$ & $40 \cdot 4$ & $94 \cdot 0$ & $2 \cdot 1$ & $3 \cdot 2$ & $16 \cdot 9$ & 41.8 \\
\hline $\mathrm{C} 24$ & $47 \cdot 3$ & $97 \cdot 0$ & $2 \cdot 3$ & 3 & $20 \cdot 4$ & $44 \cdot 5$ \\
\hline $\mathrm{C} 25$ & $52 \cdot 9$ & $99 \cdot 1$ & $2 \cdot 7$ & $3 \cdot 1$ & 23 & 44.8 \\
\hline \multicolumn{7}{|c|}{$18 \cdot 1^{\circ} \mathrm{C}$} \\
\hline \multicolumn{7}{|l|}{$\mathrm{P} 1$} \\
\hline \multicolumn{7}{|l|}{$\mathrm{P} 2$} \\
\hline \multicolumn{7}{|l|}{ P3 } \\
\hline \multicolumn{7}{|l|}{ P4 } \\
\hline \multicolumn{7}{|l|}{$\mathrm{P} 5$} \\
\hline \multicolumn{7}{|l|}{ P6 } \\
\hline \multicolumn{7}{|l|}{ P7 } \\
\hline P8 & $0 \cdot 1$ & $5 \cdot 5$ & & & & \\
\hline P9 & 58.9 & 101.4 & $2 \cdot 5$ & 3 & $23 \cdot 3$ & $43 \cdot 5$ \\
\hline P10 & 85.8 & $123 \cdot 6$ & $3 \cdot 2$ & $3 \cdot 2$ & 37.9 & 56 \\
\hline P11 & $89 \cdot 3$ & $128 \cdot 2$ & $3 \cdot 2$ & $3 \cdot 2$ & $39 \cdot 2$ & $56 \cdot 7$ \\
\hline $\mathrm{P} 12$ & $90 \cdot 2$ & $129 \cdot 8$ & $3 \cdot 1$ & $3 \cdot 2$ & $40 \cdot 7$ & 57.4 \\
\hline
\end{tabular}

Thresholds: $18.7^{\circ} \mathrm{C}$ in Cega and $18.1^{\circ} \mathrm{C}$ in Pirón. Climate change scenarios: RCP4-5 and RCP8.5 (Taylor et al. 2009).

reach, and the flow loss favours further warming of the Cega stream. Moreover, infiltration and water discharge occur at different locations to and from the underlying aquifer, particularly downstream of the $\mathrm{Ct} 3$ and $\mathrm{Ct} 4$ sites. The groundwater discharge provides resistance to thermal change forced by the atmosphere-water energy balance (O'Driscoll and DeWalle 2006), but the discharge temperature can also be affected by global warming (Kurylyk et al. 2013). At the headwaters of these streams, trout can tolerate very low temperatures under the lower growth threshold (Borgstrøm and Museth, 2005, Elliott and Elliott 2010), possibly because competition with other species and hypoxic stress do not exist.

On the basis of climate change forecasts, the thermal habitat is expected to induce the mentioned retractions of the brown trout range by the year 2100 . In the Cega stream, this reduction would affect $24 \%$ and $38 \%$ of the stream length occupied by brown trout, as estimated from 1997 and 1998 sampling events for the RCP4.5 and RCP8.5 scenarios, respectively. Differences among communities at lower and middle Cega reaches may induce differences in the threshold behaviour, and thus, the thermal window detected in the piedmont zone could cause additional losses of $11 \%$ and $18 \%$ in habitat length for the RCP4.5 and RCP8.5 scenarios. The Pirón stream reduction would affect $8 \%$ and $11 \%$ of the habitat length for the RCP4.5 and RCP8.5 scenarios, respectively; thus, relevant differences between scenarios do not exist. This may be because the stream thermal regime upstream of the P8 site is influenced by groundwater discharges, and thus, the effects of extreme summer temperatures are lessened. Moreover, other stressors such as low flow could contribute to the lower observed temperature threshold at the Pirón stream than at the Cega stream, thereby lessening the apparent effects of warming in the Pirón stream compared with the Cega stream.

Predicted thermal habitat losses are important but not as dramatic as the forecasts of other studies at higher latitudes in the Iberian Peninsula (almost the entire stream length in Almodóvar et al. 2011; 57\% of reaches in Filipe et al. 2013). We forecast a thermal habitat loss of up to $38 \%$ (56\% with warm window), despite using a more unfavourable scenario for $\mathrm{CO}_{2}$ emissions (RCP8.5) in our study (Rogelj et al. 2012). The differences in our study compared with those of other authors may be because we worked at a finer scale (more spatially intensive data) and used more recent climate models and more direct methods for downscaling and modelling stream temperature. Moreover, most of the reviewed papers used the weekly mean of the maximum temperature (i.e. Webb and Walsh 2004; Almodóvar et al. 2011; Roberts et al. 2013); we found that the use of the weekly mean added inaccuracy to the threshold study. In addition, we used daily mean temperature instead of the maximum temperature because the mean is more representative of the average conditions.

The expected high summer temperatures might disconnect the population at the middle reaches of the Cega stream by the occurrence of the warm window. This fragmentation would exacerbate the predicted decrease in the trout population of this stream. The cumulative effects of climate change and other human impacts can aggravate the negative effects on salmonids (Walters et al. 2013). Combined flow reduction and temperature increase can exacerbate the reduction of cold-water habitat (Arismendi 
et al., 2012). Water abstractions and extractions (water wells) for irrigation are particularly important in the Cega and Pirón basins. If the current use of water remains stable or increases and if forecasted precipitation reductions (IPCC 2013 and our unpublished analysis) are fulfilled, the habitat reduction of brown trout may become critical. A large number of species may have their distribution range altered; fish are particularly sensitive because connectivity between suitable areas is difficult (Abell et al. 2008). The biogeographical implications of global warming could be particularly dramatic in the Mediterranean area due to the synergistic effects of warming and flow reduction.

Additional research on the effects of climate change on freshwater fishes must be performed; however, care must be taken not to confuse the fundamental and realized niches (Pearson and Dawson 2003). Physiology can dictate the limits of fish tolerance, but these limits can be more constrained by additional biotic and abiotic restrictions, such as competition (biotic) or hydromorphology (abiotic). Trout show relative thermal plasticity at early stages of development, and this may promote adaptation if the changes are not sudden in the adaptive sense (Jensen et al. 2008); however, this plasticity is limited. Warmer events could possibly be tolerated; however, the trout realized niche appears to be narrower than the physiological limitations.

Our methodological approach is also an outcome of this study. The methodology used in this study allowed a noticeable increase in the reliability and the spatialtemporal accuracy of the forecasts, as well as a reduction in uncertainty. Downscaling is sometimes referred to as the direct interpolation of original coarse grids from climate models to points of interest. In other cases, downscaling uses grids constructed from observed data and not local observations. Both of these downscaling techniques depend too heavily on the characteristics of the interpolation technique and the density of meteorological stations, which do not take into account the local climate. We therefore preferred the complete downscaling of several climate models at our selected meteorological station. The downscaling method and the systematic error correction provide low-error results, and these methods are readily applicable to similar studies that need absolute values of the expected future changes. Likewise, the use of the latest scenarios established for climate change studies represents an update of previous forecasts.

\section{ACKNOWLEDGEMENTS}

We are grateful to the Regional Ministry of Environment and Regional Planning of the Government of Castilla y León, especially to Mariano Anchuelo, Fabián Mateo and the forest ranger team of Navafría. In addition, Ignacio Martín, Pablo Cobos and José Ramón Molina were key contributors to the electrofishing fieldwork. Judit Maroto assisted with the digital elevation model. The World Climate Research Programme's Working Group on Coupled Modelling is responsible for the 5th Coupled Model Intercomparison Project (CMIP5), and we thank the climate modelling groups for producing and sharing their model outputs. The manuscript benefited from comments of Marta González del Tánago and two anonymous reviewers. Electrofishing surveys were part of the projects titled 'Study of the fish populations of the Cega basin (Segovia)' and 'Second fish sampling in the Cega basin (Segovia)' funded by the Government of Castilla y León. The stream temperature models and climate change study were partially funded by the Ministry of Agriculture, Food and Environment through a subsidy at the Foundation for Research on Climate (FIC) and by the 7th Framework Programme of the European Union (DURERO Project. C1·3913442).

\section{REFERENCES}

Abell R, Thieme ML, Revenga C, Bryer M, Kottelat M, Bogutskaya N, Coad B, Mandrak N, Contreras Balderas S, Bussing W, Stiassny MLJ, Skelton P, Allen GR, Unmack P, Naseka A, Ng R, Sindorf N, Robertson J, Armijo E, Higgins JV, Heibel TH, Wikramanayake E, Olson D, López HL, Reis RE, Lundberg JG, Sabaj Pérez MH, Petry P. (2008). Freshwater ecoregions of the world: a new map of biogeographic units for freshwater biodiversity conservation. BioScience 58: 403-414.

Alba-Tercedor J, Sánchez-Ortega A. (1988). Un método rápido y simple para evaluar la calidad biológica de las aguas corrientes basados en el de Hellawell (1978). Limnética 4: 51-56.

Almodóvar A, Nicola GG, Ayllón, D, Elvira B. (2011). Global warming threatens the persistence of Mediterranean brown trout. Global Change Biology 18: 1549-1560.

Angilletta Jr MJ. (2009). Thermal Adaptation: A Theoretical and Empirical Synthesis. Oxford University Press: New York.

Arismendi I, Safeeq M, Johnson SL, Dunham JB, Haggerty R. (2012). Increasing synchrony of high temperature and low flow in western North American streams: double trouble for coldwater biota? Hydrobiologia 712: 61-70.

Armstrong JD, Kemp PS, Kennedy GJA, Ladle M, Milner NJ. (2003). Habitat requirements of Atlantic salmon and brown trout in rivers and streams. Fisheries Research 62: 143-170.

Ayllón D, Nicola GG, Elvira B, Parra I, Almodóvar A. (2013). Thermal carrying capacity for a thermally-sensitive species at the warmest edge of its range. PLOS ONE 8: e81354.

Beer WN, Anderson JJ. (2013). Sensitivity of salmonid freshwater life history in western US streams to future climate conditions. Global Change Biology 19: 2547-2556.

Bogan T, Mohseni O, Stefan HG. (2003). Stream temperature-equilibrium temperature relationship. Water Resources Research 39: 1245.

Borgstrom R, Museth J. (2005). Accumulated snow and summer temperaturecritical factors for recruitment to high mountain populations of brown trout (Salmo trutta L.). Ecology of Freshwater Fish 14: 375-384.

Buckley LB, Roughgarden J. (2006). Climate, competition, and the coexistence of island lizards. Functional Ecology 20: 315-322.

Caissie D. (2006). The thermal regime of rivers: a review. Freshwater Biology 51: 1389-1406.

Caissie D, El-Jabi N, St-Hilaire A. (1998). Stochastic modelling of water temperatures in a small stream using air to water relations. Canadian Joumal of Civil Engineering 25: 250-260.

Carle FL, Strub MR. (1978). A new method for estimating population size from removal data. Biometrics 34: 621-630.

Crozier LG, Hendry AP, Lawson PW, Quinn TP, Mantua NJ, Battin J, Shaw RG, Huey RB. (2008) Potential responses to climate change in organisms with 
complex life histories: evolution and plasticity in Pacific salmon. Evolutionary Applications 1: 252-270.

Eby LA, Helmy O, Holsinger LM, Young MK. (2014). Evidence of climate-induced range contractions in bull trout Salvelinus confluentus in a Rocky Mountain watershed, U.S.A. PLOS ONE 9: e98812.

Edinger JE, Duttweiler DW, Geyer JC. (1968). The response of water temperatures to meteorological conditions. Water Resources Research 4: $1137-1143$.

Elliott JM. (1981). Some aspects of thermal stress on freshwater teleosts. In Stress and Fish, Pickering AD (ed). Academic Press: London; 209-245.

Elliott JM. (2000). Pools as refugia for brown trout during two summer droughts: trout responses to thermal and oxygen stress. Journal of Fish Biology 56: 938-948.

Elliott JM, Allonby JD. (2013). An experimental study of ontogenetic and seasonal changes in the temperature preferences of unfed and fed brown trout, Salmo trutta. Freshwater Biology 58: 1840-1848.

Elliott JM, Elliott JA. (2010). Temperature requirements of Atlantic salmon Salmo salar, brown trout Salmo trutta and Arctic charr Salvelinus alpinus: predicting the effects of climate change. Journal of Fish Biology 77: 1793-1817.

Elliott JM, Hurley MA. (1999). A new energetics model for brown trout, Salmo trutta. Freshwater Biology 42: 235-246.

Elliott JM, Hurley MA. (2001). Modelling growth of brown trout, Salmo trutta, in terms of weight and energy units. Freshwater Biology 46: 679-692.

Elliott JM, Hurley MA, Fryer J. (1995). A new, improved growth model for brown trout, Salmo trutta. Functional Ecology 9: 290-298.

Evans EC, McGregor GR, Petts GE. (1998). River energy budgets with special reference to river bed processes. Hydrological Processes 12: 575-595.

Fey SB, Herren CM. (2014). Temperature-mediated biotic interactions influence enemy release of non-native species in warming environments. Ecology. (in press).

Filipe AF, Markovic D, Pletterbauer F, Tisseuil C, De Wever A, Schmutz S, Bonada N, Freyhof J. (2013). Forecasting fish distribution along stream networks: brown trout (Salmo trutta) in Europe. Diversity and Distributions 19: 1059-1071.

Finstad GA, Forseth T, Jonsson B, Bellier E, Hesthagen T, Jensen AJ, Hessen DO, Foldvik A. (2011). Competitive exclusion along climate gradients: energy efficiency influences the distribution of two salmonid fishes. Global Change Biology 17: 1703-1711.

Forseth T, Jonsson B. (1994). The growth and food ration of piscivorous brown trout (Salmo trutta). Functional Ecology 8:171-7.

Forseth T, Larsson S, Jensen AJ, Jonsson B, Näslund I, Berglund I. (2009). Thermal performance of juvenile brown trout, Salmo trutta L.: no support for thermal adaptation hypotheses. Joumal of Fish Biology 74: 133-149.

Freedman DA, Peters SC. (1984). Bootstrapping a regression equation: some empirical results. Journal of the American Statistical Association 79: 97-106.

Frost AJ, Thomson JS, Smith C, Burton HC, Davis B, Watts PC, Sneddon LU. (2013). Environmental change alters personality in the rainbow trout, Oncorhynchus mykiss. Animal Behaviour 85: 1199-1207.

Haines AT, Finlayson BL, McMahon TA. (1988). A global classification of river regimes. Applied Geography 8: 255-272.

Haldane JBS. (1956). The relation between density regulation and natural selection. Proceedings of the Royal Society B 145: 306-308.

Handeland SO, Imsland AK, Stefansson SO. (2008). The effect of temperature and fish size on growth, feed intake, food conversion efficiency and stomach evacuation rate of Atlantic salmon post-smolts. Aquaculture 283: $36 \quad 42$.

Hari RE, Livingstone DM, Siber R, Burkhardt-Holm P, Guettinger H. (2006). Consequences of climatic change for water temperature and brown trout populations in Alpine rivers and streams. Global Change Biology 12: 10-26.

Hein CL, Ohlund G, Englund G. (2013). Fish introductions reveal the temperature dependence of species interactions. Proceedings of the Royal Society B: Biological Sciences 281: 20132641.

Hughes L. (2000). Biological consequences of global warming: is the signal already. Trends in Ecology \& Evolution 15: 56-61.

Hutchinson GE. (1957). Concluding remarks. Cold Spring Harbor Symposium in Quantitative Biology 22: 415-457.

IPCC. (2013). Climate Change 2013. The Physical Science Basis. Working Group I Contribution to the Fifth Assessment Report of the Intergovernmental Panel on Climate Change Stocker TF, Qin D, Plattner G-K, Tignor M, Allen SK, Boschung J, Nauels A, Xia Y, Bex V. Midgley PM(eds). Cambridge University Press: Cambridge; 1535.
Jeffries KM, Hinch SG, Martins EG, Clark TD, Lotto AG, Patterson DA, Cooke SJ, Farrell AP, Miller KM. (2012). Sex and proximity to reproductive maturity influence the survival, final maturation, and blood physiology of Pacific salmon when exposed to high temperature during a simulated migration. Physiological and Biochemical Zoology 85: 62-73.

Jensen LF, Hansen MM, Pertoldi C, Holdensgaard G, Mensberg K-LD, Loeschcke V. (2008). Local adaptation in brown trout early life-history traits: implications for climate change adaptability. Proceedings of the Royal Society B: Biological Sciences 275: 2859-2868.

Jonsson B, Jonsson N. (2009). A review of the likely effects of climate change on anadromous Atlantic salmon Salmo salar and brown trout Salmo trutta, with particular reference to water temperature and flow. Journal of Fish Biology 75: 2381-2447.

Junta de Castilla y León. (1997). Estudio de las poblaciones piscícolas del rio Cega (Segovia). Technical Report: Estudios Biológicos, Madrid.

Kurylyk BL, Bourque CP-A, MacQuarrie KTB. (2013). Potential surface temperature and shallow groundwater temperature response to climate change: an example from a small forested catchment in east-central New Brunswick (Canada). Hydrology and Earth System Sciences Discussions 10: 3283-3326.

Lahnsteiner F, Leitner S. (2013). Effect of temperature on gametogenesis and gamete quality in brown trout, Salmo trutta. Journal of Experimental Zoology Part A: Ecological Genetics and Physiology 319: 138-148.

Leibold MA. (1995). The niche concept revisited: mechanistic models and community context. Ecology 76: 1371-1382.

Magnuson JJ, Destasio BT. (1996). Thermal niche of fishes and global warming. In Global Warming: Implications for Freshwater and Marine Fish, Wood CM, McDonald DG (eds). Cambridge University Press: Cambridge. MAGRAMA. (2014). Anuario de Aforos. Ministerio de Agricultura, Alimentación y Medio Ambiente: Madrid, Spain. http://sig.magrama.es/ aforos/visor.html

May R, McLean A. (2007). Theoretical Ecology. $3^{\text {th }}$ ed. Oxford University Press.

McBride JL, Ebert EE. (2000). Verification of quantitative precipitation forecasts from operational numerical weather prediction models over Australia. Weather \& Forecasting 15: 103-121.

Mohseni O, Stefan HG, Eriksson TR. (1998). A nonlinear regression model for weekly stream temperatures. Water Resources Research 34: 2685-2692.

Monjo R, Caselles V, Chust G. (2014). Probabilistic correction of RCM precipitation in the Basque Country (Northern Spain). Theoretical and Applied Climatology 117: 317-329.

Morita K, Fukuwaka M, Tanimata N, Yamamura O. (2010). Sizedependent thermal preferences in a pelagic fish. Oikos 119: 1265-1272.

Nukazawa K, Shiraiwa J, Kazama S. (2011). Evaluations of seasonal habitat variations of freshwater fishes, fireflies, and frogs using a habitat suitability index model that includes river water temperature. Ecological Modelling 222: 3718-3726.

O'Driscoll MA, DeWalle DR. (2006). Stream-air temperature relations to classify stream-ground water interactions in a karst setting, central Pennsylvania, USA. Journal of Hydrology 329: 140-153.

Parmesan C. (2006). Ecological and evolutionary responses to recent climate change. Annual Review of Ecology, Evolution, and Systematics 37: 637-669.

Pearson RG, Dawson TP. (2003). Predicting the impacts of climate change on the distribution of species: are bioclimate envelope models useful? Global Ecology and Biogeography 12: 361-371.

Pilgrim JM, Fang X, Stefan HG. (1998). Stream temperature correlations with air temperatures in Minnesota: implications for climate warming. JAWRA Journal of the American Water Resources Association 34: 1109-1121.

R Core Team. (2013). R: A Language and Environment for Statistical Computing. R Foundation for Statistical Computing: Vienna, Austria. http://www.R-project.org

Ribalaygua J, Torres L, Pórtoles J, Monjo R, Gaitán E, Pino MR. (2013). Description and validation of a two-step analogue/regression downscaling method. Theoretical and Applied Climatology 114: 253-269.

Roberts JJ, Fausch KD, Peterson DP, Hooten MB. (2013). Fragmentation and thermal risks from climate change interact to affect persistence of native trout in the Colorado River basin. Global Change Biology 19: 1383-1398.

Rogelj J, Meinshausen M, Knutti R. (2012). Global warming under old and new scenarios using IPCC climate sensitivity range estimates. Nature Climate Change 2: 248-253.

Ruesch AS, Torgersen CE, Lawler JJ, Olden JD, Peterson EE, Volk CJ, Lawrence DJ. (2012). Projected climate-induced habitat loss for 
salmonids in the John Day River network, Oregon, U.S.A. Conservation Biology 26 873-882.

Sánchez-Hernández J, Cobo F. (2011). Summer food resource partitioning between four sympatric fish species in central Spain (River Tormes). Folia Zoologica 60: 189-202.

Santiago JM, García de Jalón D, Alonso C, Solana J. (2013). Comportamiento térmico de dos tramos fluviales de cabecera del sistema central: impacto del embalse de Torrecaballeros (Segovia). In III Jomadas del Ingeniería del Agua Vol. 1 Valles FJ (ed). Marcombo: Barcelona, Spain; 153-160.

Spotila JR, Standora EA, Easton DP, Rutledge PS. (1989). Bioenergetics, behavior, and resource partitioning in stressed habitats: biophysical and molecular approaches. Physiological Zoology 62: 253-285.

Stefan HG, Preud'homme EB (1993) Stream temperature estimation from air temperature. Water Resources Bulletin 29: 27-45.

St-Hilaire A, Ouarda TBMJ, Bargaoui Z, Daigle A, Bilodeau L. (2011). Daily river water temperature forecast model with a k-nearest neighbour approach. Hydrological Processes 26: 1302-1310.

Taylor KE, Stouffer RJ, Meehl GA. (2009). A summary of the CMIP5 experiment design. http://cmip-pcmdi.llnl.gov/cmip5/docs/Taylor_ CMIP5_design.pdf

Theurer FD, Voos KA, Miller WJ. (1984). Instream water temperature model. Instream Flow Information Paper 16. FWS/OBS-84/15. US Fish and Wildlife Service: Washington D.C.; 343.

Tokeshi M (1993) Species abundance patterns and community structure. Advances in Ecological Research 24; 111-189.

Uppala SM, Kållberg PW, Simmons AJ, Andrae U, Bechtold VDC, Fiorino M, Gibson JK, Haseler J, Hernandez A, Kelly GA, Li X, Onogi K, Saarinen S, Sokka N, Allan RP, Andersson E, Arpe K, Balmaseda MA, Beljaars ACM, Berg LVD, Bidlot J, Bormann N, Caires S, Chevallier F, Dethof A, Dragosavac M, Fisher M, Fuentes M, Hagemann S, Hólm E, Hoskins BJ, Isaksen L, Janssen PAEM, Jenne R, Mcnally AP, Mahfouf J-F, Morcrette J-J, Rayner NA, Saunders RW, Simon P, Sterl A, Trenberth KE, Untch A, Vasiljevic D, Viterbo P, Woollen J. (2005). The ERA-40 re-analysis. Quarterly Journal of the Royal Meteorological Society 131: 2961-3012.

Vannote RL, Minshall GW, Cummins KW, Sedell JR, Cushing CE (1980). The river continuum concept. Canadian Journal of Fisheries and Aquatic Sciences 37: 130-137.

Vornanen M, Haverinen J, Egginton S. (2014). Acute heat tolerance of cardiac excitation in the brown trout (Salmo trutta fario). The Journal of Experimental Biology 217: 299-309.

Wade AJ. (2006). Monitoring and modelling the impacts of global change on European freshwater ecosystems. Science of the Total Environment 365: $3-14$.

Walters AW, Bartz KK, McClure MM. (2013). Interactive effects of water diversion and climate change for juvenile chinook salmon in the Lemhi River basin (U.S.A.): water diversion and climate change. Conservation Biology 27: 1179-1189.

Warren DR, Robinson JM, Josephson DC, Sheldon DR, Kraft CE. (2012). Elevated summer temperatures delay spawning and reduce redd construction for resident brook trout (Salvelinus fontinalis). Global Change Biology 18 1804-1811.

Webb B, Walsh A. (2004). Changing UK river temperatures and their impact on fish populations. Hydrology: Science and Practice for the 21st Century 2: 177-191.

Wehrly KE, Wiley MJ, Seelbach PW. (2003). Classifying regional variation in thermal regime based on stream fish community patterns. Transactions of the American Fisheries Society 132 $18-38$.

Wenger SJ, Isaak DJ, Luce CH, Neville HM, Fausch KD, Dunham JB, Dauwalter DC, Young MK, Elsner MM, Rieman BE, Hamlet AF, Williams JE. (2011). Flow regime, temperature, and biotic interactions drive differential declines of trout species under climate change. Proceedings of the National Academy of Sciences 108: 14175-14180.

Woodward G, Perkins DM, Brown LE. (2010). Climate change and freshwater ecosystems: impacts across multiple levels of organization. Philosophical Transactions of the Royal Society, B: Biological Sciences 365: 2093-2106.

Zorita E, Von Storch H. (1999). The analog method as a simple statistical downscaling technique: comparison with more complicated methods. Journal of Climate 12: 2474-2489.

\section{SUPPORTING INFORMATION}

Additional supporting information may be found in the online version of this article at the publisher's web site.

\section{APPENDIX A: DETERMINATION OF THE SUITABLE TIME SCALE AND UNITS FOR STUDYING THRESHOLDS}

\section{Objectives}

The suitability of using daily mean stream temperature (DM), 7-day moving average of DM, daily maximum stream temperature (DMax) and 7-day moving average of DMax to model thermal behaviour of streams and to determine the brown trout presence/absence thresholds for brown trout was contrasted.

\section{Methods}

The studied models were as follows:

- The logistic model proposed in this paper was used with daily data (mean and maximum values).

- Mohseni et al. (1998) logistic model was used with 7-day moving average data (mean and maximum values).

- A linear model was used with 7-day moving average of daily maximum summer temperatures (June to September).

Root mean square error (RMSE) was used as an indicator of the reliability of models (mean, maximum and minimum values).

Thermal thresholds were calculated from the aforementioned models. Daily mean and maximum values were studied in events of 7 consecutive days. The rationale of these choices was described in the Materials and Methods section in the body (Stream Temperature Modelling and Thermal Threshold Determination sections).

\section{Results and discussion}

The results are shown in Tables AI and AII.

The models constructed with DM stream temperature (both the events of 7 consecutive days and the 7-day moving average) were more robust because they have lower RMSE, as with maximum and minimum values.

With respect to the calculation of thresholds, the more robust indicator with the Cega stream data was DM stream temperature in events of 7 consecutive days. With the Pirón stream data, HK, BIAS, h.r. and s.d. showed identical values, although the defined thresholds were not one value but a band of values. The narrowest band was obtained from DM stream temperature (again both the events of 7 consecutive days and the 7-day moving average). At the same time, these results were more similar to each other than those obtained from DMax. 
Table AI. Average, maximum and minimum root mean square error for each model.

\begin{tabular}{|c|c|c|c|c|c|}
\hline & \multicolumn{5}{|c|}{ Root mean square error $\left({ }^{\circ} \mathrm{C}\right)$} \\
\hline & $\begin{array}{l}\text { Daily mean } \\
\text { (modified logistic } \\
\text { model) }\end{array}$ & $\begin{array}{c}\text { Daily mean } \\
7 \text {-day moving } \\
\text { average (logistic } \\
\text { model) }\end{array}$ & $\begin{array}{l}\text { Daily maximum } \\
\text { (modified logistic } \\
\text { model) }\end{array}$ & $\begin{array}{c}\text { Daily maximum } \\
\text { 7-day moving } \\
\text { average (logistic } \\
\text { model) }\end{array}$ & $\begin{array}{c}\text { Daily maximum } \\
\text { 7-day moving } \\
\text { average (linear } \\
\text { model) }\end{array}$ \\
\hline Average & $1 \cdot 35$ & $1 \cdot 16$ & 1.76 & 1.50 & $1 \cdot 38$ \\
\hline Maximum & 1.92 & 1.82 & $2 \cdot 27$ & 1.92 & 4.69 \\
\hline Minimum & 1.08 & 0.88 & $1 \cdot 32$ & 1.05 & $0 \cdot 24$ \\
\hline
\end{tabular}

Table AII. Estimated thresholds and their values for Hanssen-Kuiper (HK), BIAS, hit ratio (h.r.) and its standard deviation (s.d.) (McBride and Ebert, 2000).

\begin{tabular}{|c|c|c|c|c|c|}
\hline & \multicolumn{5}{|c|}{ Threshold determination } \\
\hline & $\begin{array}{l}\text { Daily mean } \\
\text { (7 consecutive } \\
\text { days) }\end{array}$ & $\begin{array}{l}\text { Daily mean } \\
\text { 7-day moving } \\
\text { average }\end{array}$ & $\begin{array}{c}\text { Daily maximum } \\
\text { (7 consecutive } \\
\text { days })\end{array}$ & $\begin{array}{c}\text { Daily maximum } \\
\text { 7-day moving } \\
\text { average (logistic } \\
\text { model) }\end{array}$ & $\begin{array}{c}\text { Daily maximum } \\
7 \text {-day moving } \\
\text { average (linear } \\
\text { model) }\end{array}$ \\
\hline \multicolumn{6}{|l|}{ Cega stream } \\
\hline Threshold & $18.7^{\circ} \mathrm{C}$ & $19 \cdot 5^{\circ} \mathrm{C}$ & $19.7^{\circ} \mathrm{C}$ & $21.0^{\circ} \mathrm{C}$ & $19 \cdot 2^{\circ} \mathrm{C}$ \\
\hline HK & 0.55 & 0.32 & 0.44 & $0 \cdot 34$ & 0.22 \\
\hline BIAS & 0.90 & $0 \cdot 37$ & 0.44 & $0 \cdot 34$ & 0.22 \\
\hline h.r. & $0 \cdot 86$ & $0 \cdot 36$ & 0.48 & 0.39 & 0.27 \\
\hline s.d. & $0 \cdot 12$ & $0 \cdot 23$ & 0.25 & 0.24 & 0.20 \\
\hline \multicolumn{6}{|l|}{ Pirón stream } \\
\hline Threshold & $17 \cdot 2-18 \cdot 1^{\circ} \mathrm{C}$ & $17 \cdot 5-18 \cdot 3^{\circ} \mathrm{C}$ & $18 \cdot 1-19 \cdot 5^{\circ} \mathrm{C}$ & $19 \cdot 0-\mathbf{2 0} \cdot 6^{\circ} \mathrm{C}$ & $18.6-19.9^{\circ} \mathrm{C}$ \\
\hline HK & 0.86 & 0.86 & 0.86 & 0.86 & 0.86 \\
\hline BIAS & 1.07 & 1.07 & 1.07 & 1.07 & 1.07 \\
\hline h.r. & 0.95 & 0.95 & 0.95 & 0.95 & 0.95 \\
\hline s.d. & 0.05 & 0.05 & 0.05 & 0.05 & 0.05 \\
\hline
\end{tabular}

Bold letters indicate the chosen thresholds for each model.

The upper values of the bands were chosen as thresholds because the stream temperature change ratio is insignificant above the lower value of the threshold ranges at the border of the observed trout distribution; otherwise, the threshold could be underestimated.

A thermal anomaly (a 'warm window' associated with a water infiltration area in which the gravels and boulders of the streambed are especially heated in summer by solar radiation) in an intermediate reach of the Cega stream prevented values for HK, BIAS and h.r. from being as good as those obtained from the Pirón stream data.

\section{Conclusions}

For the objectives of this paper, DM was the best solution to model thermal behaviour of the streams, and the study of events of 7 consecutive days above the threshold was better than 7-day moving average. Thus, the arguments given in the methodological description of the main body of this paper are reinforced. 